UDC 338.439

LBC 65.20

\title{
IMPORT SUBSTITUTION OF FOOD AS A DISINTEGRATION FACTOR OF THE EVOLUTIONARY DEVELOPMENT OF THE ECONOMY OF MODERN RUSSIA
}

\author{
Alla V. Litvinova \\ Volzhsky Branch of Volgograd State University, Volzhsky, Russian Federation
}

\begin{abstract}
It is shown that the gradual strengthening of integration processes in the world trade in food products with Russia's participation was accompanied by an increase in negative trends in ensuring the country's food security and determining its role as an economic recipient of the products of foreign agro-industrial complexes. The imposition of embargoes on foreign-made food products imported into Russia in response to sanctions and geopolitical threats acted as a de-integration factor for the existing system of world economic relations in the food trade and played an exceptionally positive role for Russia's economic development and its acquisition of food nondependence. Accents of import substitution shifted from the ousting of foreign producers from the Russian food market to the revival of highly effective domestic production of food products, able to meet the full needs of the country's population in quality and safe food. The scale, structure and dynamics of foreign trade turnover of food products and their domestic production for the period from 2000 to 2017, its features in the conditions of the food embargo were analyzed. The conclusion is made about the gradual strengthening of positive trends in the field of food import substitution in Russia in 2015-2017. The problems preventing the increase of efficiency of import substitution in the sphere of food production are revealed, the ways of their solution are suggested. It is substantiated that the weakest point in competitive positions of domestic food products in terms of their import substitution is the low level of safety, science intensity and innovation. To increase the effectiveness of import substitution, it is necessary to systematically solve the problems accompanying it, to develop an effective mechanism for its implementation, as well as to provide resourse and financial support through the adoption of a long-term import substitution strategy in the Russian Federation, including the sphere of food production. Domestic food producers should establish tax, credit and organizational-economic preferences, related to commodity circulation in the system of food networks.
\end{abstract}

Key words: import substitution, integration, disintegration, food commodities, export, import, domestic production, quality, competitiveness, import substitution strategy.

УДК 338.439

ББК 65.20

\section{ИМПОРТОЗАМЕЩЕНИЕ ПРОДОВОЛЬСТВИЯ КАК ДЕЗИНТЕГРАЦИОННЫЙ ФАКТОР ЭВОЛЮЦИОННОГО РАЗВИТИЯ ЭКОНОМИКИ СОВРЕМЕННОЙ РОССИИ}

\author{
Алла Владимировна Литвинова \\ Волгоградский государственный университет (Волжский филиал), \\ г. Волжский, Волгоградская область, Российская Федерация
}

Аннотация. Показано, что постепенное усиление интеграционных процессов в мировой торговле продовольственными товарами с участием России сопровождалось нарастанием негативных тенденций в обеспечении продовольственной безопасности страны и определением ее роли как экономического реципиента продукции зарубежных агропромышленных комплексов. Введение эмбарго на ввозимые в Россию продо- 
вольственные товары иностранного производства в ответ на санкции и геополитические угрозы выступило дезинтеграционным фактором сложившейся системы мирохозяйственных связей в торговле продовольственными товарами и сыграло исключительно позитивную роль для экономического развития России, обретения ею продовольственной независимости. Акценты импортозамещения сместились с вытеснения иностранных производителей с российского продовольственного рынка в плоскость возрождения высокоэффективного внутреннего производства продовольственных товаров, способного удовлетворить в полном объеме потребности населения страны в качественном и безопасном продовольствии. Проанализированы масштабы, структура и динамика внешнеторгового оборота продовольственными товарами и их внутреннего производства за период с 2000 по 2017 г, его особенности в условиях продовольственного эмбарго. Сделан вывод о постепенном усилении позитивных тенденций в области продовольственного импортозамещения в России в 2015-2017 годах. Выявлены проблемы, препятствующие повышению эффективности импортозамещения в сфере производства продовольствия, предложены пути их решения. Обосновано, что наиболее слабым местом в конкурентных позициях отечественных продовольственных товаров в аспекте их импортозамещения выступает низкий уровень безопасности, наукоемкости и инновативности. Для повышения результативности импортозамещения необходимо системное решение сопровождающих его проблем, разработка эффективного механизма его реализации, а также ресурсного и финансового обеспечения на основе принятия долгосрочной Стратегии импортозамещения в РФ, в том числе в сфере производства продовольственных товаров. Необходимо установление налоговых, кредитных и организационно-экономических, связанных с товародвижением в системе крупных продовольственных сетей, преференций отечественным производителям продовольствия.

Ключевые слова: импортозамещение, интеграция, дезинтеграция, продовольственные товары, экспорт, импорт, внутреннее производство, качество, конкурентоспособность, стратегия импортозамещения.

На протяжении более двух десятков лет новейшей истории России проблема импортозамещения производимого в стране продовольствия рассматривалась преимущественно в контексте низкой продовольственной безопасности страны, обусловленной высокой долей импорта продовольствия во внешнеторговом обороте государства и преобладанием продовольственных товаров с низкой степенью переработки в составе их экспорта.

Международное разделение труда, предусматриваюее в первую очередь специализацию каждой страны в производстве определенных видов товаров в межстрановом обмене этими товарами и нацеленное на получение странами экономической выгоды, носит объективный характер. Однако Россия, будучи интегрированной в мировое сообщество, долгое время функционировала в системе сформировавшихся торговых связей преимущественно как экономический реципиент высокотехнологической продукции зарубежных агропромышленных комплексов. Процесс интеграции продовольственных рынков различных стран, протекавший с активным участием России, хотя и основывался на формировании устойчивых взаимосвязей между ними, тем не менее оказывал отрицательное воздействие на национальную безо- пасность страны, порождал риски ее продовольственной зависимости при возникновении неблагоприятных внешних и внутренних факторов.

Впервые проблема непрерывно увеличивающегося объема поставок продовольственных товаров из-за рубежа на фоне ослабления контроля за их производством и реализацией получила законодательное закрепление в Федеральном законе от 2 января 2000 г. № 29-Ф3 «О качестве и безопасности пищевых продуктов». Был сделан первый шаг на пути разработки реального правового механизма регулирования отношений в сфере импорта продовольственного сырья и товаров, обеспечения их качества и безопасности.

В 2008 г. импортозамещение было возведено в ранг важнейшей составляющей национальной экономической политики страны. Распоряжением Правительства Российской Федерации от 17 ноября 2008 г. № 1662-р была утверждена «Концепция долгосрочного социально-экономического развития Российской Федерации на период до 2020 года». На фоне определения значимости интеграционных процессов для экономического развития страны основной акцент в концепции был поставлен на необходимость значительного замедления роста импорта во всех отраслях хозяйства и 
его замещение продовольствием преимущественно российского производства. Предполагалось, что к 2020 г. производство мяса возрастет в 1,7 раза, молока - на $27 \%$, доля импорта мясных ресурсов снизится с $34 \%$ в 2007 г. до $13 \%$ в 2020 г., доля импорта молока - с $17 \%$ до $12 \%$ соответственно.

Прорыв в политике импортозамещения был сделан в принятой в 2010 г. «Доктрине продовольственной безопасности Российской Федерации» (утв. Указом Президента РФ от 30 января 2010 г. № 120), поставившей задачу обеспечения продовольственной независимости страны на основе устойчивого развития внутреннего производства продовольствия.

Окончательный курс на импортозамещение, обеспечение продовольственной безопасности страны, снижение объемов импортируемого продовольствия, наращивание экспортного потенциала и формирование необходимых ресурсов для экспансии на мировой продовольственный рынок был взят в принятой в 2012 г. «Стратегии развития пищевой и перерабатывающей промышленности Российской Федерации на период до 2020 года» (утв. Распоряжением Правительства РФ от 17 апреля 2012 г. № 559-p). Стратегия нацелила на обеспечение к 2020 г. замещения импорта имеющей социальное значение продукции пищевой и перерабатывающей промышленности на сумму 1,3 трлн руб., в том числе: мяса скота и птицы - около 10 млн тонн, молока - до 38,2 млн тонн, овощей - до 16,5 млн тонн, плодово-ягодной продукции - до 3,8 млн тонн, что должно уменьшить поставки импортной продукции на 67,8 \%, 29,9 \%, 70,3 \%, 20 \% соответственно.

Параллельно с законодательной практикой в стране велись широкомасштабные исследования путей обеспечения продовольственной независимости и безопасности России, снижения роли импорта в обеспечении ее населения продовольствием, роста эффективности внутреннего производства продовольственных товаров.

События 2014 г., связанные с введением эмбарго на продовольственные товары из ряда иностранных государств в ответ на введенные против страны санкции, придали процессу импортозамещения резкое ускорение. Сложилась типичная, по А.М. Либману и Б.А. Хейфецу [8], модель конфликтной экономической дезинтеграции, в которой причина ослабления, нарушения связей в сложившейся системе мирохозяйственных связей обусловлена геополитическими конфликтами, при этом экономика вынуждена подстраиваться под происходящие изменения.

Несмотря на противоречивый и зачастую негативный характер дезинтеграционных процессов, разрушение сложившейся системы мирохозяйственных связей в торговле продовольственными товарами сыграло исключительно позитивную роль для экономического развития России. Пришло осознание того, что процесс импортозамещения означает не только вытеснение иностранных производителей с российского продовольственного рынка и ослабление зависимости страны от импорта продовольствия. Начиная с 2014 г. акценты импортозамещения сместились в плоскость максимального замещения ввозимых и возрождения высокоэффективного внутреннего производства продовольственных товаров, способного удовлетворить потребности населения страны в полном объеме. По сути, в стране был взят курс не только на импортозамещение, но и импортоопережение, возрождение внутреннего производства продовольственных товаров, увеличение доли высокотехнологического продовольствия в составе экспорта страны. Был принят План содействия импортозамещению в промышленности (утв. Распоряжением Правительства Российской Федерации от 30 сентября 2014 г. № 1936-p), создана Правительственная комиссия по импортозамещению (утв. Постановлением Правительства Российской Федерации от 4 августа 2015 г. № 785), разработаны многочисленные отраслевые планы импортозамещения.

События 2013-2014 гг. обусловили выход научных исследований российских ученых за пределы обсуждения только внешнеторгового оборота страны и направлений обеспечения ее продовольственной независимости и безопасности, а также самообеспечения населения России продовольствием. Активизировались научные исследования вопросов, связанных с повышением эффективности им- 


\section{МЕЖДУНАРОДНЫЕ ИНТЕГРАЦИОННЫЕ ПРОЦЕССЫ}

портозамещения в продовольственной сфере $[1 ; 3 ; 5 ; 9 ; 11]$.

К 2014 г. Россия подошла с низкими значениями показателей объема и доли экспортируемых товаров во внешнеторговом обороте страны и высокими значениями аналогичных показателей в отношении импортируемых товаров. В общем объеме экспорта РФ удельный вес продовольственных товаров за период с 2000 по 2014 г. колебался в пределах 1,6-3,8 \%, уступая минеральным продуктам, металлам и драгоценным камням, продукции химической промышленности, машинам, оборудованию и транспортным средствам. И лишь такие статьи экспорта, как древесина, текстильные изделия и обувь, кожевенное сырье, пушнина, отставали от продовольственных товаров в абсолютном и относительном выражении. Основное наполнение экспорта продовольствия обеспечивали товары низкой степени переработки - злаки, рыба, растительное масло, сахар, в то время как на долю высокотехнологических товаров (молока и сливок сгущенных, сливочного масла, круп, готовых или консервированных продуктов из мяса, готовой или консервированной рыбы и т. д.) приходилось не более 15 \%. Основная часть экспорта продовольственных товаров была направлена в страны дальнего зарубежья (так, в 2014 г. экспорт в страны СНГ составил 27,13\%, а в страны вне СНГ - 72,87 \%) (табл. 1).
Начиная с августа 2014 г., в связи с введением Россией эмбарго на продовольственные товары из стран ЕС, США, Канады, Австралии, Норвегии, Украины, Республики Албания, Черногории, Республики Исландия, княжества Лихтенштейн, структура и динамика внешнеэкономического оборота продовольственных товаров начала стремительно меняться. Несмотря на то что принятые Правительством меры были направлены на ввозимое в страну продовольствие, они существенно повлияли на его экспорт. Во-первых, выросла его доля в общем объеме экспорта страны (за 2015 г. - в 1,2 раза по сравнению с 2014 г.). В 2016 г. рост объемов экспорта продолжился и достиг 17045 млн долл., а его доля в общем объеме экспорта составила 5,97 \%.

За первое полугодие 2017 г. показатели экспорта продовольственных товаров существенно превысили аналогичные показатели двух предыдущих лет (см. табл. 2).

Во-вторых, изменилось соотношение между объемами экспорта и импорта продовольствия в пользу экспорта (см. табл. 3).

Если по итогам 2014 г. соотношение импорта и экспорта составило 2,1, то в 2015 г. оно снизилось до 1,64, в 2016 г. - до 1,46, но в первом полугодии 2017 г. возросло до 1,59.

В-третьих, несколько видоизменилась структура экспорта продовольствия. Несмотря на то что традиционно лидирующий экспорт рыбы, рыбо- и морепродуктов в натураль-

Таблиияа 1

Динамика и география экспорта продовольственных товаров Российской Федерации в 2000-2014 гг. (в фактически действовавших ценах)

\begin{tabular}{|c|c|c|c|c|c|c|c|c|c|c|}
\hline \multirow[b]{2}{*}{ Показатели } & \multicolumn{2}{|c|}{2000} & \multicolumn{2}{|c|}{2005} & \multicolumn{2}{|c|}{2010} & \multicolumn{2}{|c|}{2013} & \multicolumn{2}{|c|}{2014} \\
\hline & $\begin{array}{l}\text { млн } \\
\text { долл. } \\
\text { США } \\
\end{array}$ & $\begin{array}{l}\text { в \% к } \\
\text { итогу }\end{array}$ & $\begin{array}{l}\text { млн } \\
\text { долЛ. } \\
\text { США } \\
\end{array}$ & $\begin{array}{l}\text { в \% к } \\
\text { итогу }\end{array}$ & $\begin{array}{r}\text { млн } \\
\text { долл. } \\
\text { США } \\
\end{array}$ & $\begin{array}{l}\text { в \% к } \\
\text { итогу }\end{array}$ & $\begin{array}{l}\text { млн } \\
\text { долл. } \\
\text { США } \\
\end{array}$ & $\begin{array}{l}\text { в \% к } \\
\text { итогу }\end{array}$ & $\begin{array}{r}\text { млн } \\
\text { долл. } \\
\text { США } \\
\end{array}$ & $\begin{array}{l}\text { в \% к } \\
\text { итогу }\end{array}$ \\
\hline Экспорт всего & 103093 & 100 & 241473 & 100 & 397068 & 100 & 525976 & 100 & 497834 & 100 \\
\hline $\begin{array}{l}\text { Экспорт продовольствия } \\
\text { всего }\end{array}$ & 1623 & 1,6 & 4492 & 1,9 & 8755 & 2,2 & 16262 & 3,8 & 18981 & 3,8 \\
\hline $\begin{array}{l}\text { Экспорт продовольствия в } \\
\text { страны СНГ }\end{array}$ & 739 & 5,3 & 2184 & 6,7 & 2771 & 4,6 & 4913 & 6,6 & 5150 & 8,0 \\
\hline $\begin{array}{l}\text { Экспорт продовольствия в } \\
\text { страны дальнего зарубежья }\end{array}$ & 884 & 1,0 & 2308 & 1,1 & 5984 & 1,8 & 11349 & 2,5 & 13832 & 3,2 \\
\hline $\begin{array}{l}\text { Доля экспорта продоволь- } \\
\text { ствия в страны СНГ в об- } \\
\text { щем объеме его экспорта, \% }\end{array}$ & 45,53 & - & 48,62 & - & 31,65 & - & 30,21 & - & 27,13 & - \\
\hline $\begin{array}{l}\text { Доля экспорта продоволь- } \\
\text { ствия в страны дальнего } \\
\text { зарубежья в общем объеме } \\
\text { его экспорта, \% }\end{array}$ & 54,47 & - & 51,38 & - & 68,35 & - & 69,79 & - & 72,87 & - \\
\hline
\end{tabular}

Примечание. Составлено по: [13, с. 632-633, 636]. 
Динамика объема экспорта продовольственных товаров и его доли в общем объеме экспорта Российской Федерации в 2000-2017 гг.

\begin{tabular}{|c|c|c|c|c|c|c|c|c|c|c|c|}
\hline \multicolumn{2}{|c|}{2000} & \multicolumn{2}{|c|}{2010} & \multicolumn{2}{|c|}{2014} & \multicolumn{2}{|c|}{2015} & \multicolumn{2}{|c|}{2016} & \multicolumn{2}{|c|}{ январь - июль 2017} \\
\hline $\begin{array}{c}\text { млн } \\
\text { долл. } \\
\text { США }\end{array}$ & $\begin{array}{c}\text { доля в об- } \\
\text { щем объе- } \\
\text { ме экспор- } \\
\text { та страны, } \\
\%\end{array}$ & $\begin{array}{c}\text { млн } \\
\text { долл. } \\
\text { США }\end{array}$ & $\begin{array}{c}\text { доля в об- } \\
\text { щем объе- } \\
\text { ме экспор- } \\
\text { та страны, } \\
\text { \% }\end{array}$ & $\begin{array}{c}\text { млн } \\
\text { долл. } \\
\text { США }\end{array}$ & $\begin{array}{c}\text { доля в об- } \\
\text { щем объе- } \\
\text { ме экспор- } \\
\text { та страны, } \\
\text { \% }\end{array}$ & $\begin{array}{c}\text { млн } \\
\text { долл. } \\
\text { США }\end{array}$ & $\begin{array}{c}\text { доля в об- } \\
\text { щем объе- } \\
\text { ме экспор- } \\
\text { та страны, } \\
\text { \% }\end{array}$ & $\begin{array}{c}\text { млн } \\
\text { долл. } \\
\text { США }\end{array}$ & $\begin{array}{c}\text { доля в об- } \\
\text { щем объе- } \\
\text { ме экспор- } \\
\text { та страны, } \\
\text { \% }\end{array}$ & $\begin{array}{c}\text { млн } \\
\text { долл. } \\
\text { США }\end{array}$ & $\begin{array}{c}\text { доля в об- } \\
\text { щем объе- } \\
\text { ме экспор- } \\
\text { та страны, } \\
\text { \% }\end{array}$ \\
\hline 1623 & 1,6 & 8755 & 2,2 & 18981 & 3,8 & 14395 & 4,61 & 17045 & 5,97 & 10010 & 5,24 \\
\hline
\end{tabular}

Примечание. Составлено по: [13, с. $632 ; 17$, с. 112, 113, 115; 18, с. 105, 111; 19, с. 118, 120$]$.

Таблица 3

Объемы экспорта и импорта продовольствия в 2014-2017 гг.

\begin{tabular}{|l|c|c|c|c|c|c|c|}
\hline \multirow{2}{*}{ Показатель } & \multicolumn{2}{|c|}{ январь - июль 2017 } & \multicolumn{2}{|c|}{2016} & \multicolumn{2}{|c|}{2015} & 2014 \\
\cline { 2 - 8 } & $\begin{array}{c}\text { млн долл. } \\
\text { США }\end{array}$ & $\begin{array}{c}\text { в \% к } \\
2015 \text { г. }\end{array}$ & $\begin{array}{c}\text { млн долл. } \\
\text { США }\end{array}$ & $\begin{array}{c}\text { в \% к } \\
2015 \text { г. }\end{array}$ & $\begin{array}{c}\text { млн долл. } \\
\text { США }\end{array}$ & $\begin{array}{c}\text { в \% к } \\
2014 \text { г. }\end{array}$ & $\begin{array}{c}\text { млн долл. } \\
\text { США }\end{array}$ \\
\hline $\begin{array}{l}\text { Объем экспорта продовольствия, } \\
\text { всего }\end{array}$ & 10010 & 118,8 & 17045 & 105,2 & 14395 & 83,7 & 18981 \\
\hline $\begin{array}{l}\text { Объем импорта продовольствия, } \\
\text { всего }\end{array}$ & 15969 & 116,8 & 24902 & 93,7 & 23717 & 65,1 & 39905 \\
\hline
\end{tabular}

Примечание. Составлено по: [13, с. $633 ; 17$, с. 115-116; 18, с. 111; 19, с. 120].

ном выражении вырос (108,4 \% в 2015 г. по отношению к 2014 г.), его стоимостная оценка снизилась до 97,4 \% к 2014 г., а в декабре 2016 г. - до 91,7 \% к декабрю предыдущего года $[17$, с. $118 ; 19$, с. 123$]$. Объем вывозимой муки вырос в 2015 г. в 2 раза, но в 2016 г. снизился до 89,4 \% по отношению к 2015 г. [17, c. 116]. Четко обозначилась тенденция роста объемов экспорта высокотехнологического продовольствия. Например, за январь - июль 2016 г. рост объема кондитерских мучных изделий составил 102,4 \% к январю - июлю 2015 г., в июле 2017 г. - 108,5\% к июлю 2016 года. Рост объемов макаронных изделий в январе - июле 2017 г. составил 111,7\% к январю - июлю 2016 г., а масла подсолнечного - 134,4 \% за аналогичный период времени [18, c. 111-112].

До 2013 г. включительно наблюдался стабильный рост объемов импортируемого в страну продовольствия, несмотря на то что его доля в общем объеме импорта вплоть до 2013 г. неуклонно снижалась. По итогам 2012 г. доля ввезенного продовольствия в общем объеме импорта снизилась до 12,8 \% с 21,8 \% в 2000 г., хотя в 2013 г. наметился ее незначительный рост до уровня 13,7 \% (см. табл. 4). В структуре импорта продовольственных товаров преобладал импорт из стран дальнего зарубежья (в 2013 г. он составил 85,56 \%, в то время как из стран СНГ - 14,44 \% в общем объеме импорта продовольствия). В составе стран дальнего зарубежья, из которых осуществлялся импорт продовольственных товаров, ведущую роль играли страны Евросоюза (в 2013 г. на их долю приходилось 42,6 \% объема импорта страны).

В составе импорта были представлены как продовольственные товары низкой степени переработки (сельскохозяйственное сырье: хлебные злаки, сахар-сырец, какао-бобы; овощи, фрукты, в первую очередь - тропические; мясо птицы и крупного рогатого скота), так и широкий ассортимент товаров высокой степени переработки (кофе, чай, крупы, растительное масло, рыбные и мясные консервы, фруктовые и овощные соки, пиво, крепкие спиртные напитки, шоколадные изделия) [12, с. 616].

В связи с введением Россией в августе 2014 г. эмбарго на продовольственные товары структура и динамика их импорта претерпели существенные изменения. Объем импорта в натуральном выражении резко снизился. Так, по итогам 2014 г. он уменьшился на 3350 млн долл., а за 2015 г. объем ввезенного в страну продовольствия снизился до 23717 млн долл., что к 2014 г. составило лишь 63,8 \%. Страны дальнего зарубежья ввезли в 2015 г. продоволь- 
Динамика и география импорта продовольствия в Россию (в фактически действовавших ценах) в 2000-2014 гг.

\begin{tabular}{|c|c|c|c|c|c|c|c|c|c|c|c|}
\hline \multicolumn{12}{|c|}{ Показатели } \\
\hline \multicolumn{2}{|c|}{2000} & \multicolumn{2}{|c|}{2005} & \multicolumn{2}{|c|}{2010} & \multicolumn{2}{|c|}{2012} & \multicolumn{2}{|c|}{2013} & \multicolumn{2}{|c|}{2014} \\
\hline $\begin{array}{c}\text { млн долл. } \\
\text { США }\end{array}$ & $\begin{array}{l}\text { в \% к } \\
\text { итогу }\end{array}$ & $\begin{array}{c}\text { млн долл. } \\
\text { США }\end{array}$ & $\begin{array}{l}\text { в \% к } \\
\text { итогу }\end{array}$ & $\begin{array}{c}\text { млн долл. } \\
\text { США }\end{array}$ & $\begin{array}{l}\text { в \% к } \\
\text { итогу }\end{array}$ & $\begin{array}{c}\text { млн долл. } \\
\text { США }\end{array}$ & $\begin{array}{l}\text { в \% к } \\
\text { итогу }\end{array}$ & $\begin{array}{c}\text { млн долл. } \\
\text { США }\end{array}$ & $\begin{array}{l}\text { в \% к } \\
\text { итогу }\end{array}$ & $\begin{array}{c}\text { млн долл. } \\
\text { США }\end{array}$ & $\begin{array}{l}\text { в \% к } \\
\text { итогу }\end{array}$ \\
\hline \multicolumn{12}{|c|}{ Импорт, всего } \\
\hline 33880 & 100 & 98708 & 100 & 228912 & 100 & 317263 & 100 & 315298 & 100 & 32806 & 100 \\
\hline \multicolumn{12}{|c|}{ Импорт продовольствия, всего } \\
\hline 7384 & 21,8 & 17430 & 17,7 & 36398 & 15,9 & 40655 & 12,8 & 43255 & 13,7 & 39905 & 13,9 \\
\hline \multicolumn{12}{|c|}{ Импорт продовольствия из стран СНГ } \\
\hline 2072 & 17,9 & 3874 & 20,4 & 6152 & 19,4 & 5196 & 11,6 & 6337 & 16,3 & 5792 & 17,7 \\
\hline \multicolumn{12}{|c|}{ Импорт продовольствия из стран дальнего зарубежья } \\
\hline 5312 & 23,8 & 13556 & 17,0 & 30246 & 15,3 & 35459 & 13,0 & 36918 & 13,4 & 34114 & 13,4 \\
\hline
\end{tabular}

Примечание. Составлено по: [13, с. 633-634].

ственные товары на сумму 19814 млн руб., что к 2014 г. составило лишь 65,1\%. Доля стран ЕС в поставках продовольствия в Россию в 2015 г. снизилась до 46,5 \% по сравнению с 2014 года. Объем импорта продовольственных товаров в натуральном выражении по перечню товаров, запрещенному с 2014 г. к ввозу на территорию Российской Федерации, в 2015 г. составил 9 017,8 тыс. тонн (78,3 \% к 2014 г.) [19, с. 127-128]. Сокращение импорта продовольственных товаров и изменение географии его поставок стали вынужденным ответом России на внешние ограничения и угрозы, но это, по сути, является закономерным продолжением начавшегося в середине 2000-х гг. активного процесса снижения зависимости страны от импортируемого, как из государств дальнего зарубежья, так и из государств СНГ, продовольствия.

Однако начиная с 2016 г. импорт продовольствия в Россию начал постепенно восста- навливать свои позиции. Так, объем импорта в 2016 г. в соотношении к 2015 г. составил уже 93,7 \% (из стран дальнего зарубежья - 91,9\%, из стран СНГ - 102,6 \%), а уже за январь июль 2017 г. этот показатель достиг значения 116,8 \% на фоне резкого роста объема импорта из стран дальнего зарубежья, в том числе из стран ЕС (114,9 \% и 116,6 \% соответственно по отношению к январю - июлю 2016 г.), что можно расценивать как негативную тенденцию (см. табл. 5).

Ситуация в сфере импортозамещения в Волгоградской области типична для страны в целом.

В товарной структуре экспорта Волгоградской области на долю продовольственных товаров и сельскохозяйственного сырья для их производства по итогам 2014 г. пришлось лишь 6,4 \%. Экспортные поставки продовольственных товаров и сырья для их производства возросли на 23 \% к уровню 2013 г. и со-

Таблица 5

Состав и структура импорта продовольствия в Россию в 2015-2017 гг.

\begin{tabular}{|l|c|c|c|c|c|c|c|c|c|}
\hline \multicolumn{1}{|}{$\begin{array}{c}\text { Объемы импорта и } \\
\text { страны - импортеры } \\
\text { продовольствия }\end{array}$} & $\begin{array}{c}\text { млн долл. } \\
\text { США }\end{array}$ & $\begin{array}{c}\text { в \% к янва- } \\
\text { рю - июлю } \\
2016 \text { г. }\end{array}$ & $\begin{array}{c}\text { в \% к } \\
\text { итогу }\end{array}$ & $\begin{array}{c}\text { млн долл. } \\
\text { США }\end{array}$ & $\begin{array}{c}\text { в \% к } \\
2015 \text { г. }\end{array}$ & $\begin{array}{c}\text { в \% к } \\
\text { итогу }\end{array}$ & $\begin{array}{c}\text { млн долл. } \\
\text { США }\end{array}$ & $\begin{array}{c}\text { в \% к } \\
2014 \text { г. }\end{array}$ & $\begin{array}{c}\text { в \% к } \\
\text { итогу }\end{array}$ \\
\hline $\begin{array}{l}\text { Объем импорта про- } \\
\text { довольствия, всего }\end{array}$ & 15969 & 116,8 & 100 & 24902 & 93,7 & 100 & 23717 & 63,8 & 83,5 \\
\hline $\begin{array}{l}\text { В том числе: } \\
\text { - из стран дальнего } \\
\text { зарубежья }\end{array}$ & 12889 & 114,9 & 80,7 & 20407 & 91,9 & 81,9 & 19814 & 65,1 & 83,9 \\
\hline - из стран ЕС & 3467 & 116,6 & 21,7 & 5632 & 99,0 & 22,6 & 5112 & 46,5 & 21,6 \\
\hline $\begin{array}{l}\text { - из стран - участ- } \\
\text { ниц СНГ }\end{array}$ & 3080 & 125,4 & 19,3 & 4496 & 102,6 & 18,1 & 3904 & 72,3 & 16,5 \\
\hline
\end{tabular}

Примечание. Составлено по: [17, с. 123; 18, с. 119; 19, с. 120, 128-129]. 
ставили 273,1 млн долл., однако в экспорте данной категории товаров также преобладало сельскохозяйственное сырье - злаки (34 \%, или 87,9 млн долл. США, что в 1,61 раза больше, чем за 2013 г.), масличные семена (2,6 \%). В незначительных объемах экспортировались продукты переработки овощей и фруктов, продукция мукомольно-крупяной промышленности, какао и продукты из него и т. д. В структуре импорта Волгоградской области в 2014 г. удельный вес продовольственных товаров составил 7,0 \% и распределился следующим образом: табачное сырье (44,6 \% стоимости), масличные семена $(25,5 \%)$, злаки $(12 \%)$, мясо и мясные субпродукты (7,2 \%), фрукты $(4,5$ \%). Импортные поставки масличных семян относительно 2013 г. увеличились на $34 \%$, злаков - в 1,9 раза, мяса и мясных субпродуктов - в 3,5 раза, фруктов - в 3,4 раза [2].

В 2015 г. произошло значительное сокращение внешнеторгового оборота Волгоградской области, что обусловлено неблагоприятной геополитической ситуацией и ужесточением санкционной политики Евросоюза по отношении к России. Объемы экспорта региональной продукции по итогам 2015 г. составили 2052 млн долл., объемы импорта в регион - 1036 млн долл. США, то есть $48 \%$ и $59 \%$ от уровня соответствующих показателей 2014 года. Продовольственные товары и сельскохозяйственное сырье по итогам 2015 г. оставались приоритетным направлением экспортной составляющей внешней торговли области (на их долю пришлось 12,2%). Однако в стоимостном выражении экспорт продовольственных товаров снизился на $40 \%$.

В составе импорта на долю продовольственных товаров и сельскохозяйственного сырья в 2015 г. пришлось 8,8 \% (на 1,8 п.п. больше по сравнению с 2014 г.), однако объем импорта продовольственных товаров сократился на $32 \%$ [7].

В 2016 г. негативные тенденции во внешнеторговом обороте усилились. В 1-м полугодии 2016 г. по данным таможенной статистики объемы экспорта региональной продукции составили 584 млн долл., объемы импорта в регион $-310,2$ млн долЛ., то есть $54 \%$ и $56 \%$ от уровня соответствующих показателей 2015 года. Доля предприятий Волгоградской области в товарообороте Юга России в 1-м полугодии 2016 г. сократилась до 10,0 \% его стоимости (1-е полугодие 2015 г. - 16,7 \%). На этом фоне стоимостные объемы экспорта продовольственных товаров и сельскохозяйственного сырья с территории региона сократились на 45 \%. Основную часть экспорта в указанной укрупненной товарной группе составили злаковые культуры (около $20 \%$ и и табачные изделия (около $40 \%$ ).

Стоимостные объемы импорта в январе июне 2016 г. оказались ниже показателей 2015 г. на 44 \% и составили 310,2 млн долларов. На $34 \%$ сократились поставки продовольственных товаров и сельскохозяйственного сырья [6].

Таким образом, современная экспортно-импортная база Волгоградской области характеризуется высокой долей импорта продовольствия во внешнеторговом обороте региона и преобладанием продовольственных товаров с низкой степенью переработки в составе их экспорта. В последние два года на фоне резкого снижения внешнеторгового оборота региона наблюдается уменьшение объемов как импорта, так и экспорта продовольствия, однако снижение экспорта опережает снижение его импорта. Позитивной тенденцией выступает рост доли экспортируемых продовольственных товаров в общем объеме экспорта региона (с $6,4 \%$ в 2014 г. до $12,2 \%$ в 2015 г. и 15,46\% в 1-м полугодии 2016 г.). Однако при этом наблюдался также рост доли импорта продовольственных товаров (с 7,0\% в 2014 г. до 8,8 \% в 2015 г. с последующим незначительным снижением до 8,0 \% в 1-м полугодии 2016 г.).

Параллельно с изменением состава и структуры внешнеторгового оборота продовольственными товарами в стране и ее регионах активно шел процесс перестройки системы их внутреннего производства.

Индекс производства пищевых продуктов в целом по России в 2015 г. по сравнению с 2014 г. составил 103,1\%, в 2016 г. по сравнению с 2015 г. - 103,1\%, в январе - августе 2017 г.-104,8 \% к аналогичному периоду предыдущего года $[17$, с. $21 ; 18$, с. $24-25 ; 19$, с. 26], то есть имел положительный тренд.

В разрезе отдельных видов продовольственных товаров объемы их производства в целом по России в январе - августе 2017 г. по 


\section{МЕЖДУНАРОДНЫЕ ИНТЕГРАЦИОННЫЕ ПРОЦЕССЫ}

отношению к январю - августу 2016 г. значительно возросли. В их составе однозначно лидируют рыба сушеная (166,1 \%), мясо рыбы свежее или охлажденное $(120,4 \%)$, овощи $(139,4 \%)$, масла растительные $(113,8 \%)$, крупы (113,4 \%), свинина (109,4 \%), масло сливочное (107,2 \%), изделия макаронные (105,6 \%), мясо птицы (105,1%). Однако снизились объемы производства соков, молочных продуктов, муки [18, с. 25-26].

Сравнение динамики объемов производства продовольственных товаров в Волгоградской области и по России за период с 2010 по 2017 г. показывает отсутствие в регионе, в отличие от страны в целом, четкого положительного тренда в объемах выпуска продовольствия. За исследованный период индекс регионального производства достиг своего минимального значения в 2016 г. (91,1 \%), снизившись на 1,5\% по сравнению с 2015 г., в то время как в целом по России индекс объема производства продовольственных товаров к 2016 г. вырос и достиг 103,1 \%. В 2017 г. негативная тенденция динамики индекса производства продовольственных товаров в Волгоградской области прекратилась. В январе - августе 2017 г. по сравнению с соответствующим периодом предыдущего года объем производства пищевых продуктов в регионе возрос на $16,4 \%$, подтвердив общероссийскую динамику (табл. 6).

Однако основой импортозамещения должно стать не только увеличение объемов внутреннего производства продовольственных товаров, но и повышение их качества и безопасности. Ежегодно в стране признается опасной значительная часть продовольственных товаров практически из всех товарных групп, причем по итогам 2016 г. качество таких отечественных товаров, как мясо и птица, колбасные изделия, рыбная продукция, кондитерские изделия, масло животное и др., уступало качеству импортных товаров (см. табл. 7). Отсутствие документов, подтверждающих соответствие требованиям безопасности, нарушение правил маркировки, условий хранения, превышение сроков годности - основные причины опасности отечественных продовольственных товаров. По итогам первого полугодия 2017 г. лидерами некачественных и опасных продовольственных товаров стали мясо и птица, колбасные изделия, рыба, сыры, хлеб и хлебобулочные изделия (см. табл. 8).

Несмотря на имеющиеся проблемы, значительное число отечественных продовольственных товаров обладает высоким качеством, что проявляется в оптимальном сочетании их сенсорных характеристик, состава применяемого сырья, внешнего вида и других показателей. Однако в оценке позиций отечественных продовольственных товаров в конкурентной борьбе за замещение иностранных аналогов необходимо исходить из того, что эффективный, основанный на импортозамещении, продовольственный рынок - это рынок высокотехнологических, наукоемких продовольственных товаров. Вместе с тем низкий уровень наукоемкости и инновативности выступает основной проблемой обеспечения устойчивых конкурентных позиций отечественных продуктов питания. В настоящее время на долю товаров с высокой добавлен-

Таблица 6

\section{Динамика индекса производства продовольственных товаров} в России и Волгоградской области

\begin{tabular}{|c|c|c|}
\hline \multirow{2}{*}{ Период времени } & \multicolumn{2}{|c|}{ Индекс производства, в \% к предыдущему году } \\
\cline { 2 - 3 } & по Волгоградской области & в целом по России \\
\hline 2010 & 95,8 & 103,2 \\
\hline 2011 & 103,7 & 103,9 \\
\hline 2012 & 100,8 & 104,1 \\
\hline 2013 & 107,1 & 100,6 \\
\hline 2014 & 104,4 & 102,5 \\
\hline 2015 & 92,6 & 103,1 \\
\hline 2016 & 91,1 & 103,1 \\
\hline январь - август 2017 & 107,5 & 104,8 \\
\hline
\end{tabular}

Примечание. Составлено по: [4, с. $165 ; 13$, с. $350 ; 15$, с. $2 ; 16$, с. $2 ; 17$, с. $21 ; 18$, с. $24-25 ; 19$, с. 26$]$. 
Импортозамещение продовольствия как дезинтеграционный фактор эволюционного развития экономики

Таблица 7

Качество отечественных и импортных товаров, поступивших на потребительский рынок в 2000-2016 гг.

\begin{tabular}{|c|c|c|c|c|c|c|c|c|c|c|c|c|}
\hline \multirow{3}{*}{$\begin{array}{c}\text { Вид продовольственных } \\
\text { товаров }\end{array}$} & \multicolumn{12}{|c|}{ Забраковано и снижено в сортности, в \% от общего объема проинспектированных товаров } \\
\hline & \multicolumn{2}{|c|}{2000} & \multicolumn{2}{|c|}{2010} & \multicolumn{2}{|c|}{2013} & \multicolumn{2}{|c|}{2014} & \multicolumn{2}{|c|}{2015} & \multicolumn{2}{|c|}{2016} \\
\hline & $\begin{array}{c}\text { отеч. } \\
\text { това- } \\
\text { ров }\end{array}$ & $\begin{array}{c}\text { имп. } \\
\text { това- } \\
\text { ров }\end{array}$ & $\begin{array}{c}\text { отеч. } \\
\text { това- } \\
\text { ров }\end{array}$ & $\begin{array}{c}\text { имп. } \\
\text { това- } \\
\text { ров }\end{array}$ & $\begin{array}{c}\text { отеч. } \\
\text { това- } \\
\text { ров }\end{array}$ & $\begin{array}{c}\text { имп. } \\
\text { това- } \\
\text { ров }\end{array}$ & $\begin{array}{c}\text { отеч. } \\
\text { това- } \\
\text { ров }\end{array}$ & $\begin{array}{c}\text { имп. } \\
\text { това- } \\
\text { ров }\end{array}$ & $\begin{array}{c}\text { отеч. } \\
\text { това- } \\
\text { ров }\end{array}$ & $\begin{array}{c}\text { имп. } \\
\text { това- } \\
\text { ров }\end{array}$ & $\begin{array}{c}\text { отеч. } \\
\text { това- } \\
\text { ров }\end{array}$ & $\begin{array}{c}\text { имп. } \\
\text { това- } \\
\text { ров }\end{array}$ \\
\hline Мясо и птица & 8,2 & 53,5 & 8,1 & 5,8 & 13,1 & 5,7 & 1,6 & 3,9 & 5,4 & 3,3 & 3,3 & 2,9 \\
\hline Изделия колбасные & 14,8 & 57,5 & 6,8 & 1,5 & 2,0 & 0,4 & 0,6 & 1,3 & 2,7 & 2,3 & 2,1 & 0,7 \\
\hline $\begin{array}{l}\text { Продукция рыбная пи- } \\
\text { щевая товарная (без } \\
\text { рыбных консервов) }\end{array}$ & 28,5 & 36,2 & 12,0 & 14,7 & 5,8 & 3,3 & 4,1 & 18,4 & 8,3 & 19,4 & 1,7 & 1,0 \\
\hline $\begin{array}{l}\text { Консервы мясные и мя- } \\
\text { сорастительные }\end{array}$ & 62,1 & 71,9 & 2,7 & 4,5 & 0,4 & 0,0 & 0,3 & 0,1 & 0,3 & 0,5 & 1,3 & 5,9 \\
\hline Макаронные изделия & 26,2 & 31,9 & 1,4 & 0,2 & 0,4 & 0,0 & 0,2 & 0,4 & 0,6 & 0,3 & 0,4 & 10,2 \\
\hline Кондитерские изделия & 17,1 & 21,4 & 9,0 & 5,6 & 3,9 & 26,6 & 2,3 & 25,4 & 4,4 & 6,1 & 2,4 & 1,6 \\
\hline Масло животное & 23,9 & 13,7 & 6,0 & 0,2 & 1,7 & 0,2 & 3,7 & 1,7 & 5,7 & 0,2 & 4,0 & 1,2 \\
\hline Растительные масла & 32,5 & 18,1 & 0,9 & 0,3 & 0,2 & 0,3 & 0,4 & 1,6 & 0,7 & 0,6 & 0,1 & 0,3 \\
\hline Сыры & 21,9 & 27,1 & 3,2 & 1,8 & 1,3 & 4,3 & 2,5 & 3,9 & 1,9 & 4,1 & 1,7 & 0,6 \\
\hline $\begin{array}{l}\text { Водка и ликероводоч- } \\
\text { ные изделия }\end{array}$ & 10,2 & 35,7 & 3,9 & 0,7 & 0,5 & 0,8 & 6,1 & 1,0 & 3,3 & 0,5 & 6,1 & 7,5 \\
\hline Пиво & 17,2 & 26,6 & 3,6 & 4,4 & 3,1 & 3,5 & 1,3 & 5,3 & 4,9 & 10,5 & 1,3 & 1,7 \\
\hline
\end{tabular}

Примечание. Составлено по: [13, с. 493; 14, с. 489; 17, с. 99].

Таблица 8

Качество продовольственных товаров, поступивших на розничные рынки в первом полугодии 2017 г.

\begin{tabular}{|c|c|c|c|c|c|}
\hline \multirow{3}{*}{$\begin{array}{c}\text { Вид } \\
\text { продовольственных товаров }\end{array}$} & \multicolumn{5}{|c|}{$\begin{array}{c}\text { Установлены ненадлежащее качество и (или) опасность товаров, } \\
\text { в \% от количества отобранных образцов }\end{array}$} \\
\hline & \multirow[b]{2}{*}{ Всего } & \multicolumn{4}{|c|}{ Из них по причинам: } \\
\hline & & $\begin{array}{c}\text { отсутствия документов, } \\
\text { подтверждающих качество } \\
\text { и безопасность продукции }\end{array}$ & $\begin{array}{c}\text { нарушения } \\
\text { правил мар- } \\
\text { кировки } \\
\end{array}$ & $\begin{array}{c}\text { нарушения } \\
\text { условий } \\
\text { хранения } \\
\end{array}$ & $\begin{array}{c}\text { нарушения } \\
\text { сроков год- } \\
\text { ности } \\
\end{array}$ \\
\hline Мясо и птица & 4,2 & 2,5 & 0,9 & 0,4 & 0,0 \\
\hline Изделия колбасные & 4,3 & 0,3 & 3,0 & 0,0 & 1,0 \\
\hline Рыба живая и охлажденная & 4,1 & 0,0 & 0,0 & 3,5 & 0,0 \\
\hline Консервы мясные & 1,6 & 0,0 & 0,0 & 0,0 & 1,6 \\
\hline Изделия кондитерские & 3,2 & 0,0 & 2,3 & 0,0 & 0,9 \\
\hline Сыры & 5,4 & 0,0 & 2,5 & 0,0 & 0,0 \\
\hline Хлеб и хлебобулочные изделия & 6,1 & 0,0 & 5,7 & 0,0 & 0,7 \\
\hline
\end{tabular}

Примечание. Составлено по: [18, с. 94].

ной стоимостью в общем объеме производимых в России продовольственных товаров приходится не более 5 \%. Однако по оценкам $\mathrm{OOH}$, сделанным еще в 2000 г., минимальный уровень высокотехнологических товаров в общем объеме их внутреннего производства, обеспечивающий продовольственную безопасность и устойчивые конкурентные позиции любой страны на мировом рынке продовольствия, должен составлять 10-15\% [10, с. 302].

Для того чтобы соответствовать требованиям наукоемкости и инновативности, непрерывно возрастающим запросам потребителей, качество продовольствия должно формироваться как результат опирающейся на инновации активной инвестиционной деятельности товаропроизводителей в техническое перевооружение, новые технологии, проведение научно-исследовательских работ, изучение потребительских предпочтений и т. д.

Анализ показателей, отражающих результативность инновационной деятельности производителей продовольственных товаров, показывает следующее.

В период с 2011 по 2015 г. наблюдалась положительная динамика объема производ- 


\section{МЕЖДУНАРОДНЫЕ ИНТЕГРАЦИОННЫЕ ПРОЦЕССЫ}

ства инновационных продовольственных товаров в стоимостном выражении (в 2015 г. он в 1,6 раза превысил значения 2011 г.) (табл. 9).

Анализ инновационной активности организаций по типам внедряемых инноваций (табл. 10) показал, что производство продовольственных товаров характеризуется преобладанием технологических инноваций. Так, доля организаций, осуществляющих технологические инновации, превысила в 2015 г. долю организаций, прибегающих к процессным инновациям, в 2,1 раза, а к продуктовым инновациям - в 1,6 раза.

Несмотря на то что удельный вес производителей пищевых продуктов, осуществляющих продуктовые инновации, относитель- но невелик (6,5 \% по итогам 2015 г.), производство пищевых продуктов по данному показателю опережает другие виды экономической деятельности (например, добычу полезных ископаемых - в 4,6 раза). Достаточно высокий удельный вес организаций, внедряющих продуктовые инновации, свидетельствует о стремлении производителей продовольственных товаров создавать новое качество этих товаров посредством внедрения новейших видов сырья, полуфабрикатов, готовых продуктов, высокофункциональной упаковки и т. д.

С 2011 по 2013 г. объем затрат предприятий, производящих продовольственные товары, на цели осуществления технологических инноваций вырос в 2,4 раза, причем при-

Таблийа 9

Объем инновационных товаров, работ и услуг организаций по видам экономической деятельности

\begin{tabular}{|l|c|c|c|c|c|c|}
\hline \multicolumn{1}{|c|}{ Вид деятельности } & \multicolumn{2}{|c|}{2011} & \multicolumn{2}{|c|}{2014} & \multicolumn{2}{c|}{2015} \\
\cline { 2 - 7 } & млн руб. & $\begin{array}{c}\text { в \% от обще- } \\
\text { го объема } \\
\text { отруженных } \\
\text { товаров }\end{array}$ & млн руб. & $\begin{array}{c}\text { в \% от обще- } \\
\text { го объема } \\
\text { отгруженных } \\
\text { товаров }\end{array}$ & $\begin{array}{c}\text { млн руб. } \\
\text { го объема } \\
\text { отгруженных } \\
\text { товаров }\end{array}$ \\
\hline $\begin{array}{l}\text { Всего (добыча полезных ис- } \\
\text { копаемых, обрабатывающие } \\
\text { производства, производство } \\
\begin{array}{l}\text { и распределение электро- } \\
\text { энергии, газа и воды) }\end{array}\end{array}$ & 1847370,4 & 6,1 & 3037407,3 & 8,2 & 3258254,6 & 7,9 \\
\hline $\begin{array}{l}\text { В том числе: } \\
\text { производство пищевых про- } \\
\text { дуктов, включая напитки, и } \\
\text { табака }\end{array}$ & 116193,1 & 4,1 & 180282,7 & 5,0 & 209289,3 & 4,8 \\
\hline
\end{tabular}

Примечание. Составлено по: [12, с. 502; 14, с. 528].

Таблица 10

Инновационная активность организаций по типам инноваций, в \%

\begin{tabular}{|c|c|c|c|c|c|c|c|c|c|}
\hline \multirow{3}{*}{ Вид деятельности } & \multicolumn{9}{|c|}{$\begin{array}{c}\text { Удельный вес организаций в общем числе обследованных организа- } \\
\text { ций, осуществлявших: }\end{array}$} \\
\hline & \multicolumn{3}{|c|}{$\begin{array}{c}\text { технологические } \\
\text { инновации }\end{array}$} & \multicolumn{3}{|c|}{$\begin{array}{c}\text { процессные } \\
\text { инновации }\end{array}$} & \multicolumn{3}{|c|}{$\begin{array}{c}\text { продуктовые } \\
\text { инновации }\end{array}$} \\
\hline & 2011 & 2014 & 2015 & 2011 & 2014 & 2015 & 2011 & 2014 & 2015 \\
\hline Bcero & 9,6 & 9,7 & 9,5 & 5,5 & 5,7 & 5,6 & 5,9 & 5,9 & 5,7 \\
\hline $\begin{array}{l}\text { В том числе: } \\
\text { - добыча полезных ископаемых }\end{array}$ & 6,8 & 6,5 & 5,8 & 5,1 & 5,2 & 4,8 & 2,3 & 1,7 & 1,4 \\
\hline $\begin{array}{lcc}- & \text { производство пищевых } \\
\text { включая напитки, и табака } & \\
\end{array}$ & 9,6 & 10,3 & 10,2 & 4,9 & 5,1 & 4,8 & 6,1 & 6,2 & 6,5 \\
\hline - текстильное и швейное производство & 7,2 & 7,5 & 9,0 & 4,0 & 4,4 & 4,6 & 3,9 & 5,0 & 6,2 \\
\hline $\begin{array}{l}\text { - металлургическое производство и про- } \\
\text { изводство готовых металлических изделий }\end{array}$ & 13,3 & 13,0 & 12,8 & 8,2 & 8,6 & 7,9 & 7,4 & 7,1 & 7,1 \\
\hline $\begin{array}{l}\text { - производство машин, оборудования, } \\
\text { транспортных средств }\end{array}$ & 15,3 & 14,6 & 12,9 & 6,6 & 6,5 & 5,6 & 11,3 & 10,9 & 9,8 \\
\hline - химическое производство & 21,4 & 21,4 & 23,3 & 11.7 & 11.6 & 12,8 & 15,2 & 15,2 & 15,8 \\
\hline
\end{tabular}

Примечание. Составлено по: [12, с. 497; 14, с. 523]. 
рост объема указанных затрат был преимущественно вызван увеличением расходов на приобретение машин и оборудования, а также на исследования и разработки. Начавшее в 2014 г. снижение объема затрат на технологические инновации однозначно можно охарактеризовать как негативную тенденцию. Однако снижение в их составе затрат на исследования и разработки, на приобретение машин, оборудования, патентов, лицензий и проведение маркетинговых исследований сопровождалось ростом затрат на приобретение новых технологий, программных средств, проведение дизайнерских работ (табл. 11).

Таким образом, анализ процессов, отражающих результативность импортозамещения в России, показывает следующие позитивные тенденции:

- во-первых, снижение объемов импорта, его доли в общем объеме внешнеторгового оборота продовольственными товарами, однако уровень, обеспечивающий полную продовольственную безопасность страны (минимально - 15 \%), не достигнут;

- во-вторых, объем экспорта, его доля в общем объеме внешнеторгового оборота продовольственными товарами постепенно повышается;

- в-третьих, наблюдается рост объемов внутреннего производства продовольственных товаров;

- в-четвертых, повышается удельный вес организаций, осуществляющих производ- ство пищевых продуктов с использованием технологических, процессных, продуктовых инноваций; при этом наблюдается увеличение затрат на технологические инновации в части приобретения новых технологий, лицензий, прав на патенты, а также производственного проектирования.

Негативными тенденциями выступают следующие:

- сохраняется высокая доля высокотехнологических продовольственных товаров в общем объеме импорта;

- объем традиционных экспортных сырьевых товаров, его доля в общем объеме экспорта не только не снижается, но и возрастает;

- показатели объемов внутреннего производства и импортозамещения социально значимых продовольственных товаров не соответствуют целевым установкам «Концепции долгосрочного социально-экономического развития Российской Федерации на период до 2020 года» и «Стратегии развития пищевой и перерабатывающей промышленности Российской Федерации на период до 2020 года»;

- повышение объемов высокотехнологических продовольственных товаров, их доли в общем объеме экспорта не носит систематический характер и затрагивает лишь незначительный ряд позиций товарной номенклатуры;

- наблюдается снижение затрат на исследования и разработки, на приобретение машин, оборудования, патентов, лицензий, проведение маркетинговых исследований в со-

Затраты на технологические инновации организаций, осуществляющих производство пищевых продуктов

\begin{tabular}{|l|c|c|c|c|c|}
\hline \multicolumn{2}{|c|}{ Затраты } & \multicolumn{4}{c|}{ Год } \\
\cline { 2 - 5 } & 2011 & 1012 & 2013 & 2014 & 2015 \\
\hline $\begin{array}{l}\text { Затраты на технологические инновации всего, } \\
\text { млн руб. }\end{array}$ & 12562,9 & 16908,0 & 29974,3 & 25864,4 & 20143,0 \\
\hline В том числе по видам инновационной деятельности & & & \\
\hline Исследования и разработки & 1690,9 & 3807,0 & 4970,2 & 2080,6 & 2920,6 \\
\hline Приобретение машин и оборудования & 7695,8 & 9376,1 & 21393,6 & 16470,1 & 12409,7 \\
\hline Приобретение новых технологий & 48,6 & 29,8 & 36,9 & 62,0 & 95,4 \\
\hline Приобретение прав на патенты, лицензий & 5,1 & 19,7 & 5,1 & 11,6 & 5,4 \\
\hline Приобретение программных средств & 74,0 & 25,2 & 47,1 & 27,2 & 48,0 \\
\hline Инжиниринг & 855,8 & 2004,7 & 1723,5 & 3587,6 & 1290,0 \\
\hline Другие виды подготовки производства, дизайн & 1223,6 & 474,3 & 696,7 & 383,9 & 1619,1 \\
\hline Обучение и подготовка персонала & 124,9 & 93,7 & 25,5 & 12,8 & 17,4 \\
\hline Маркетинговые исследования & 247,2 & 334,2 & 191,7 & 178,3 & 129,1 \\
\hline Прочие затраты & 602,1 & 763,0 & 889,1 & 3061,9 & 1613,5 \\
\hline
\end{tabular}

Примечание. Составлено по: [12, с. 499-501; 14, с. 527] 
ставе технологических инноваций, которые внедряют производители продовольственных товаров.

Для повышения результативности импортозамещения необходимо системное решение сопровождающих его проблем, разработка эффективного механизма его реализации, а также ресурсного и финансового обеспечения. Решению этих задач будет способствовать принятие Стратегии импортозамещения в РФ, в которой должны быть отражены: анализ состояния и основных системных проблем импортозамещения; формирование совокупности индикаторов и показателей результативности импортозамещения; разработка организационно-экономического механизма импортозамещения и мер, направленных на его развитие и повышение результативности; определение сроков, этапов, рисков, контроля реализации стратегии и источников ее финансирования. Особое внимание в стратегии должно быть уделено импортозамещению в сфере производства продовольствия, выступающей системообразующим элементом экономики страны, формирующей агропродовольственный рынок, обеспечивающей продовольственную и экономическую безопасность России. Основной акцент в стратегии импортозамещения продовольствия должен быть сделан на способы достижения и ресурсное обеспечение инновационной деятельности российских производителей продовольствия, внедрение ими прогрессивных технологий, новейших видов сырья и готовой продукции. Несмотря на определенные успехи в обеспечении инновативности качества отечественных продовольственных товаров, проявляющемся в росте затрат производителей на технологические инновации в форме приобретения новых технологий, их явно недостаточно для решения проблем конкурентоспособности российского продовольствия с учетом современных экономических реалий. Необходимо установление финансовых, в первую очередь налоговых, преференций производителям продовольствия. Предлагается предоставление налоговых каникул инновационно активным предприятиям по переработке сырья и выпуску готовой пищевой продукции, установление для них гибкой шкалы ставок по налогам (например, налогу на прибыль организа- ций) в зависимости от результативности инновационной деятельности. Объективно необходимым является повышение для указанных организаций доступности кредитных ресурсов, принятие мер предельно упрощенного механизма их участия в цепях товародвижения, формируемых крупными торговыми продовольственными сетями. Разработка и реализация стратегии позволит повысить эффективность государственной экономической политики в области импортозамещения продовольствия, обеспечить население страны качественными и безопасными продуктами питания, развивать отечественный агропромышленный комплекс, оперативно реагировать на внутренние и внешние угрозы стабильности продовольственного рынка страны.

\section{СПИСОК ЛИТЕРАТУРЫ}

1. Артемова, Е. И. Обеспечение конкурентоспособности регионального агропромышленного комплекса в условиях импортозамещения / Е. И. Артемова, Е. В. Плотникова // Политематический сетевой электронный научный журнал Кубанского государственного аграрного университета. - 2016. № 119. - C. 524-538.

2. Внешнеэкономическая деятельность Волгоградской области в 2014 году // Комитет экономики Волгоградской области : сайт. - Электрон. текстовые дан. - Режим доступа: http://economics. volganet.ru/foreign/statistics/ (дата обращения: 03.11.2017). - Загл. с экрана.

3. Вождаева, Н. Г. Управление в сельском хозяйстве: проблемы и перспективы / Н. Г. Вождаева, И. В. Волков // Вестник НГИЭИ. - 2015. - № 5 (48). C. 16-24.

4. Волгоградская область в цифрах. 2015 : крат. сб. / Террит. орган Федер. службы гос. статистики по Волгогр. обл. - Волгоград : Волгоградстат, 2016. $-376 \mathrm{c}$.

5. Грешонков, А. М. Необходимость и перспективы формирования стратегической модели обеспечения продовольственной безопасности государства / А. М. Грешонков, В. М. Юрьев // Социально-экономические явления и процессы. -2015 . T. 10, № 4. - C. 30-35.

6. Итоги внешнеэкономической деятельности Волгоградской области в 1 полугодии 2016 года // Комитет экономики Волгоградской области : сайт. - Электрон. текстовые дан. - Режим доступа: http://economics.volganet.ru/foreign/statistics/ (дата обращения: 28.10.2017). - Загл. с экрана. 
7. Итоги внешнеэкономической деятельности Волгоградской области в 2015 году // Комитет экономики Волгоградской области : сайт. - Электpoн. текстовые дан. - Режим доступа: http:// economics.volganet.ru/foreign/statistics/ (дата обращения: 28.10.2017). - Загл. с экрана.

8. Либман, А. М. Модели экономической дезинтеграции. Интеграция и дезинтеграция / А. М. Либман, Б. А. Хейфец // Евразийская экономическая интеграция. - 2011. -№ 2 (11). - С. 37-42.

9. Маханько, Г. В. Национальная продовольственная безопасность и продовольственная независимость России в условиях санкций / Г. В. Маханько, А. С. Волохатых // Политематический сетевой электронный научный журнал Кубанского государственного аграрного университета. - 2016. № 116. - С. 407-423.

10. Наука и высокие технологии России на рубеже третьего тысячелетия (социально-экономические аспекты развития) / авт. коллектив: В. Л. Макаров, А. Е. Варшавский. - М. : Наука, 2001. -636 с.

11. Проблемы и перспективы развития АПК и сельских территорий : монография / Е. В. Бодрова, А. Н. Бугара, М. Ф. Григорьев [и др.] / под общ. ред. С. С. Чернова. - Новосибирск : Изд-во ЦРНС, 2015. Кн. 2. -202 c.

12. Российский статистический ежегодник. 2014 : стат. сб. / Росстат. - М., 2014. - 693 с.

13. Российский статистический ежегодник 2015 : стат. сб. / Росстат. - М., 2015. - 728 с.

14. Российский статистический ежегодник 2016 : стат. сб. / Росстат. - М., 2016. - 725 с.

15. Социально-экономическое положение Волгоградской области за 2016 год // Волгоградская областная Дума : сайт. - Электрон. текстовые дан. - Режим доступа: http://volgoduma.ru/analitika/issledovaniyaanalitika/sotsialno-ekonomicheskoe-polozhenievolgogradskoy-oblasti-analiticheskie-obzory.html (дата обращения: 08.10.2017). - Загл. с экрана.

16. Социально-экономическое положение Волгоградской области за январь - август 2017 года // Волгоградская областная Дума : сайт. - Электрон. текстовые дан. - Режим доступа: http://volgoduma.ru/ analitika/issledovaniya-analitika/sotsialnoekonomicheskoe-polozhenie-volgogradskoy-oblastianaliticheskie-obzory.html (дата обращения: 10.10.2017). - Загл. с экрана.

17. Социально-экономическое положение России. Январь 2017 г. : стат. сб. / Росстат. - М., 2017. - 388 c.

18. Социально-экономическое положение России. Январь - август 2017 г. : стат. сб. / Росстат. М., 2017. - $407 \mathrm{c}$.

19. Социально-экономическое положение России. Январь - декабрь 2015 г. : стат. сб. / Росстат. - М., 2015. -382 c.

\section{REFERENCES}

1. Artemova E.I., Plotnikova E.V. Obespechenie konkurentosposobnosti regionalnogo agropromyshlennogo kompleksa $\mathrm{v}$ usloviyakh importozameshcheniya [Ensuring the Competitiveness of the Regional Agro-Industrial Complex under the Conditionsof Import Substitution]. Politematicheskiy setevoy elektronnyy nauchnyy zhurnal Kubanskogo gosudarstvennogo agrarnogo universiteta [Polytechnical Network Electronic Scientific Journal of the Kuban State Agrarian University], 2016, no. 119, pp. 524-538.

2. Vneshneekonomicheskaya deyatelnost Volgogradskoy oblasti v 2014 godu [Foreign Economic Activity of the Volgograd Region in 2014]. Komitet ekonomiki Volgogradskoy oblasti [Committee for Economy of the Volgograd Region]. URL: http:// economics.volganet.ru/foreign/statistics/. (accessed November 3, 2017).

3. Vozhdaeva N.G., Volkov I.V. Upravlenie v selskom khozyaystve: problemy i perspektivy [Management in Agriculture: Problems and Prospects]. Vestnik NGIEI, 2015, no. 5 (48), pp. 16-24.

4. Volgogradskaya oblast $v$ tsifrakh. 2015: krat. sb. [Volgograd Region in Figures. 2015: a Short Compilation]. Territ. organ Feder. sluzhby gos. statistiki po Volgogr. obl. [Territorial Body of the Federal Service of State Statistics in the Volgograd Region]. Volgograd, Volgogradstat Publ., 2016. 376 p.

5. Greshonkov A.M., Yuryev B.M. Neobkhodimost i perspektivy formirovaniya strategicheskoy modeli obespecheniya prodovolstvennoy bezopasnosti gosudarstva [Necessity and Prospects for the Formation ofa Strategic Model for Ensuring the State's Food Security]. Sotsialno-ekonomicheskie yavleniya i protsessy [SocioEconomic Phenomena and Processes], 2015, vol. 10, no. 4, pp. 30-35.

6. Itogi vneshneekonomicheskoy deyatelnosti Volgogradskoy oblasti v 1 polugodii 2016 goda [Results of Foreign Economic Activity of the Volgograd Region in the First Half of 2016]. Komitet ekonomiki Volgogradskoy oblasti [Committee for Economy of the Volgograd Region]. URL: http://economics. volganet.ru/foreign/statistics/. (accessed October 28, 2017).

7. Itogi vneshneekonomicheskoy deyatelnosti Volgogradskoy oblasti v 2015 godu [Results of Foreign Economic Activity of the Volgograd Region in 2015]. Komitet ekonomiki Volgogradskoy oblasti [Committee for Economy of the Volgograd Region]. URL: http:/economics.volganet.ru/foreign/statistics/. (accessed October 28, 2017).

8. Libman A.M., Heyfets B.A. Modeli ekonomicheskoy dezintegratsii. Integratsiya $\mathrm{i}$ dezintegratsiya [Models of Economic Disintegration. 


\section{МЕЖДУНАРОДНЫЕ ИНТЕГРАЦИОННЫЕ ПРОЦЕССЫ}

Integration and Disintegration]. Evraziyskaya ekonomicheskaya integratsiya [Eurasian Economic Integration], 2011, no. 2(11), pp. 37-42.

9. Makhanko G.V., Volokhatykh A.S. Natsionalnaya prodovolstvennaya bezopasnost i prodovolstvennaya nezavisimost Rossii v usloviyakh sanktsiy [National Food Security and Food Independence of Russia in the Conditions of Sanctions]. Politematicheskiy setevoy elektronnyy nauchnyy zhurnal Kubanskogo gosudarstvennogo agrarnogo universiteta [Polythematic Network Electronic Scientific Journal of the Kuban State Agrarian University], 2016, no. 116, pp. 407-423.

10. Makarov V.L., Varshavskiy A.E. Nauka $i$ vysokie tekhnologii Rossii na rubezhe tretyego tysyacheletiya (sotsialno-ekonomicheskie aspekty razvitiya) [Science and High Technologies of Russia at the Turn of the Third Millennium (Socio-Economic Aspects of Development)]. Moscow, Nauka Publ., 2011.636 p.

11. Bodrova E.V., Bugara A.N., Grigoryev M.F. Problemy $i$ perspektivy razvitiya APK $i$ selskikh territoriy: monografiya [Problems and Perspectives of the Development of Agroindustrial Complex and Rural Territories: Monograph]. Novosibirsk, Izd-vo TsRNS, 2015.202 p.

12. Rossiyskiy statisticheskiy ezhegodnik. 2014: stat. sb. [Russian Statistical Yearbook. 2014: Collection]. Moscow, 2014. 693 p.

13. Rossiyskiy statisticheskiy ezhegodnik. 2015: stat. sb. [Russian Statistical Yearbook. 2015: Collection]. Moscow, 2015. 728 p.
14. Rossiyskiy statisticheskiy ezhegodnik. 2016: stat. sb. [Russian Statistical Yearbook. 2016: Collection]. Moscow, 2016. 725 p.

15. Sotsialno-ekonomicheskoe polozhenie Volgogradskoy oblasti za 2016 god [Social and Economic Situation of the Volgograd Region for 2016]. Volgogradskaya oblastnaya Duma [Volgograd Regional Duma]. URL: http://volgoduma.ru/analitika/ issledovaniya-analitika/sotsialno-ekonomicheskoepolozhenie-volgogradskoy-oblasti-analiticheskieobzory.html. (accessed October 8, 2017).

16. Sotsialno-ekonomicheskoe polozhenie Volgogradskoy oblasti za yanvar - avgust 2017 goda [Social and Economic Situation of the Volgograd Region for January-August of 2017]. Volgogradskaya oblastnaya Duma [Volgograd Regional Duma]. URL: $\mathrm{http} / /$ volgoduma.ru/analitika/issledovaniya-analitika/ sotsialno-ekonomicheskoe-polozhenievolgogradskoy-oblasti-analiticheskie-obzory.html. (accessed October 10, 2017).

17. Sotsialno-ekonomicheskoe polozhenie Rossii. Yanvar 2017 g.: stat. sb. [Socio-Economic Situation in Russia. January 2017: Collection]. Moscow, 2017. 388 p.

18. Sotsialno-ekonomicheskoe polozhenie Rossii. Yanvar - avgust 2017 g.: stat. sb. [SocioEconomic Situation in Russia. January-August 2017]. Moscow, 2017. 407 p.

19. Sotsialno-ekonomicheskoe polozhenie Rossii. Yanvar - dekabr 2015 g.: stat. sb. [SocioEconomic Situation in Russia. January - December 2015]. Moscow, 2015. 382 p.

\section{Information about the Author}

Alla V. Litvinova, Doctor of Sciences (Economics), Professor, Head of Department of Finance and Credit, Volzhsky Branch of Volgograd State University, 40 let Pobedy St., 11, 404133 Volzhsky, Russian Federation, litvinova_av@mail.ru.

\section{Информация об авторе}

Алла Владимировна Литвинова, доктор экономических наук, профессор, заведующий кафедрой финансов и кредита, Волжский филиал ФГАОУ «Волгоградский государственный университет», ул. 40 лет Победы, 11, 404133 г. Волжский, Российская Федерация, litvinova_av@mail.ru. 